\title{
Learning Analytics: Issues on the Pupil-Teacher Ratio in Public Primary Schools in Nigeria
}

https://doi.org/10.3991/ijet.v14i10.10129

\author{
Abiodun A Opanuga, Hilary I Okagbue ${ }^{(\varpi)}$, Pelumi E Oguntunde, \\ Sheila A Bishop, Opeyemi P Ogundile \\ Covenant University, Ota, Nigeria \\ hilary.okagbue@covenantuniversity.edu.ng
}

\begin{abstract}
Pupil-teacher ratio (PTR) is one of the key measurements of quality education. This article presents the pupil-teacher ratio for 133 public primary schools in a local government area (LGA) of Ogun State, Nigeria. The data were obtained from a complete enumeration of the records of each school. It was discovered that the average PTR obtained from the data analysis is higher than the national average. Using PTR equals 35 as a benchmark of Nigeria, only $25(19 \%)$ schools out of the 133 schools considered have an acceptable PTR (below 35), 52 (39\%) schools have a moderate PTR (between 35 and 50) and 56 $(42 \%)$ schools have unacceptable and high PTR (above 50). This article shows that there is high pupil-teacher ratio in the country's public primary schools. This research will be helpful in the following; educational evaluation and assessment, audit and quality assurance, decision makers in the Ministry of Education in gap analysis for recruitment purposes, assessing the level of implementation of policies on education and monitoring of the progress made in attaining development sustainable goals (SDG) as it relates to access to quality education.
\end{abstract}

Keywords-Education, Learning analytics, Pupil-teacher ratio, Smart campus, Statistics, Teacher, Nigeria

\section{Introduction}

The pupil-teacher ratio is the total number of pupils in a particular school divided by the total number of qualified teachers. The format for computation of PTR used in this article is the same used by the UNESCO [1]. PTR is often confused with "class size" even though; they are different but similar metrics in educational evaluation. PTR is a key indicator in measuring quality and equity in public primary education. Other indicators as listed by [2] include, but not limited to: educational qualification of the teacher, health condition and intellectual quotient of the pupil, psychological variables such as externalizing or internalizing behavior [3], motivation of the teachers [4], the quality of teaching and teaching aids [5], school-home distance, quality of curriculum and educational policies [6-9], social and environmental factors. 
Several authors who have presented similar research papers showed that smaller PTR is desirable for effective learning to take place, citing that higher number of pupils in a class reduces the attention given to each pupil by the teacher, which consequently affect the academic performance, especially at practical classes. Historically, education in general has not received the necessary and adequate funding from governments in Nigeria and that have resulted in its falling standard. One of the manifestations is the prevalence of high PTR of which this article portrays. The official PTR in Nigeria, according to [2] is 35 which are often higher in urban areas. The high PTR in the urban areas can be attributed to economic migration from the rural to urban areas.

PTR is a widely researched concept in educational evaluation, audit and management. Stakeholders such as parents [10], voters [11], researchers [12], economists [13] believe that low PTR is good for their wards. Privately owned or funded schools seem to have a low PTR [14-15] and often times, policies are formulated and implemented by government to reduce PTR of public primary schools by increasing space allocation [16], building more schools to boost school enrolment [17], subsidy strategies [18], resource expansion and improved budgetary allocations [19-20], progressive pedagogy [21], class-size reduction and staffing. The strategies are necessary to address the issue of fading productivity of schooling [22] and encourage early childhood education [23].

This work presents an analysis of data of the number of teachers and the pupils in government funded primary schools across the LGA considered. Low or high PTR is just one of the concerns of primary education, others can be seen in [24-28].

\section{$2 \quad$ Literature Review}

There are diverse views on the impact of PTR on academic performance, human capital development, economy, after school life and so on. Coincidentally, some of the views about the effect of PTR have proven to be insignificant on the educational, sociological and psychological variables. A survey of literature is done to outline the perceived relationship, independence and associations of PTR and some studied variables.

Generally, researchers have found out that PTR and other factors are significant predictors of learning or educational attainment of pupils. These are presented in Table 1. It should be noted that the perceived significant relationship may not account for hidden or unexplained variables that were not pictured in by the various researchers.

In addition, it has been observed that the following have a significant effect on PTR; expansion of charter schools [38], infant mortality [39] and skill-biased technological changes [40]. 
Table 1. Authors' contributions to the general significance of PTR on some factors or variables

\begin{tabular}{|l|c|}
\hline \multicolumn{1}{|c|}{ Factors } & Authors \\
\hline Per pupil non-teaching expenditure, PTR, teaching experience and instructional hours. & {$[29]$} \\
\hline Age, socioeconomic background and PTR & {$[30]$} \\
\hline Expenditure per student, PTR, and families' background & {$[31]$} \\
\hline School management, teaching and learning resources, PTR and syllabus coverage & {$[32]$} \\
\hline $\begin{array}{l}\text { Sanitation facilities in school, enrolment ratio, environment, drinking water, space- } \\
\text { student ratio, PTR and dropout and repetition rates }\end{array}$ & {$[33]$} \\
\hline Educational expenditure and PTR & {$[34]$} \\
\hline PTR & {$[35-37]$} \\
\hline
\end{tabular}

\subsection{Pupil-teacher ratio as a significant positive predictor}

PTR has been found to have a positive correlation or a link or association with some educational, sociodemographic, psychological, socioeconomic, pedagogical and environmental variables. A look at previous works in the literature showed that the association is often studied simultaneously with other identified variable or school input. In the developing countries, free education inevitably increases the PTR [41] because of increased access and subscription, and high enrolment rate while in the developed countries, free education reduces the PTR because of calculated efforts are done to increase the carrying capacity of schools and recruitment of more qualified teachers.

Five broad areas were identified here, which are:

- Effect of PTR on teachers

- Educational attainment

- Cognitive abilities

- Life after school

- Drop-out

Effect of PTR on teachers: The educational qualification and wages were identified to be positively correlated with PTR [42]. Highly skilled teachers are normally assigned to big classes for the purposes of maximum impact and return on investment. Ordinarily, high wages are paid as compensation. On the other hand, high PTR often leads to high incidence of teachers' sickness absenteeism [43], voice disorders [44] and burn outs [45].

Effect of PTR on educational attainment: PTR has been found to be less significant positively correlated with educational attainment of the pupils [46-47], although, parental education [48], strong pedagogical strategies [49] and ICT adoption [50] have more impact.

Effect of PTR on cognitive ability: PTR has been found to be positively related to the ability of pupils to perform well on cognitive tests. It has been identified to be true in mathematics [51] and language proficiency [52] tests. 
Effect of PTR on life after school: PTR has been found to be positively correlated with labor, employment and some aspects of life after school. These come in the form of larger capital to labor ratio [53], higher enumeration and job satisfaction [54], benefit from less intergenerational mobility [55], decreased probability of being unemployed after school [56] and health lifestyle [57].

Effect of PTR on pupil dropout: Pupils are more likely to drop out of school (early school-leaving) if the school they attend is associated with a higher PTR or lower expenditure per pupil [58-59]. These are predominant features in developing countries, where teacher pupil interaction and advising is very minimal because of high PTR.

\subsection{Teacher-pupil ratio as significant negative predictor}

PTR has been found to have a negative correlation or association with some educational, sociodemographic, psychological, socioeconomic, pedagogical and environmental variables. That is the high PTR leads to a reduction of the effects of the studied variable or school input and vice versa.

Low PTR has been identified to lead to high returns on education [60], which readily reflects on the cognitive performance of the pupils [61]. High level of monetary investments in education measured as expenditure per pupil leads to lower PTR [6263]. The consequences of such spending are restriction of access [64-65] and engagement of inexperienced teachers and a reduction of teachers' remuneration [66]. On the other hand, a reduction in the educational facilities leads to high PTR [67-68]. This scenario is readily found in the developing countries where government reduces the school fees without investing in the infrastructure that will cater for the increased number of pupils anticipated as a result of the fee reduction. The increased enrollment rate will inevitably snowballed into high PTR. The geographical size is also related to PTR as increasing district sizes reduce the PTR [69-70].

The quality of education has been found to be negatively correlated with PTR [71], as the perceived quality [72] and examination pass rates [73] erode with increasing PTR. Although the trend can be reversed by recruitment of additional teachers [74]. The teachers, on the other hand, often demand for high incentives in order to deliver efficiently [75], which leads to low PTR, increasing pupil-teacher interaction [76] and enhancing job satisfaction [77].

Other areas where PTR has been identified to be negatively correlated with some variables include: foreign direct investments (FDI) [78], district poverty rates [79], manufacturing productivity [80], environmental noise levels [81], gay-straight alliances [82], elevated suicide ideation [83] and crime [84].

\subsection{PTR is not a significant predictor}

The last case is the instances where the PTR has no significant effect on the studied variable or educational input presented by the various authors. That is, neither no link exists between PTR and the variables and factors, nor does PTR contribute to their significance. Some of such instances of zero correlation are listed. 
PTR was found neither to be related to geographical boundaries [85] nor contributes to bullying behaviors [86]. Furthermore, PTR is not associated with matriculation pass rate [87], career choice of pupils after school [88], educational qualifications or remuneration [89-90] and greenness performance [91]. Finally, authors have reported that there seem to be no link between PTR and educational attainment [92-93] or cognitive performance of pupils [94-95].

\section{$3 \quad$ Materials and Methods}

The details on how the data was obtained from the study area and the statistical methodology are presented.

\subsection{Study area and data}

The data were obtained from the records of 133 public primary schools in a local government area (LGA) in Ogun State, Nigeria. The records were collected from the official school and staff registers at the various schools with the condition that the data should be used for academic and scholarly purposes only. Privately funded and special primary schools were not considered. The raw data contains the number of teachers and the pupils in government funded primary schools across the LGA considered.

\subsection{Computation of PTR}

The PTR can be calculated using the formula;

$$
\text { PTR }=\frac{\text { Total Number of Pupils in a school }}{\text { Total Number of Teachers in a school }}
$$

\subsection{Statistical analysis}

Descriptive statistics and ranking were used to present information obtained from the analysis of the data. Similar analysis has been performed on some related educational data [96-100].

\section{$4 \quad$ Results and Discussion}

\subsection{PTR Computation and descriptive statistics}

The pupil-teacher ratio was computed for each of the schools and presented in Table 2. Thereafter, the results of the descriptive statistics of the number of students and the teachers are presented. 
Paper-Learning Analytics: Issues on the Pupil-Teacher Ratio Dataset in Public Primary Schools...

Table 2. The number of pupils and teachers and the PTR in the 133 schools

\begin{tabular}{|c|c|c|c|c|c|}
\hline $\mathbf{S} / \mathbf{N}$ & Teacher & Male pupil & Female pupil & Total pupil & Pupil-Teacher Ratio \\
\hline 1 & 9 & 275 & 257 & 532 & 59.11 \\
\hline 2 & 15 & 280 & 285 & 565 & 37.67 \\
\hline 3 & 11 & 297 & 278 & 575 & 52.27 \\
\hline 4 & 12 & 231 & 201 & 432 & 36.00 \\
\hline 5 & 12 & 325 & 252 & 577 & 48.08 \\
\hline 6 & 8 & 200 & 162 & 362 & 45.25 \\
\hline 7 & 12 & 242 & 272 & 514 & 42.83 \\
\hline 8 & 14 & 265 & 267 & 532 & 38.00 \\
\hline 9 & 17 & 339 & 311 & 650 & 38.24 \\
\hline 10 & 14 & 379 & 325 & 704 & 50.29 \\
\hline 11 & 12 & 322 & 306 & 628 & 52.33 \\
\hline 12 & 13 & 379 & 356 & 735 & 56.54 \\
\hline 13 & 12 & 346 & 278 & 624 & 52.00 \\
\hline 14 & 8 & 228 & 220 & 448 & 56.00 \\
\hline 15 & 13 & 270 & 277 & 547 & 42.08 \\
\hline 16 & 8 & 239 & 208 & 447 & 55.88 \\
\hline 17 & 10 & 200 & 143 & 343 & 34.30 \\
\hline 18 & 15 & 342 & 309 & 651 & 43.40 \\
\hline 19 & 9 & 228 & 201 & 429 & 47.67 \\
\hline 20 & 12 & 324 & 324 & 648 & 54.00 \\
\hline 21 & 6 & 83 & 93 & 176 & 29.33 \\
\hline 22 & 10 & 170 & 179 & 349 & 34.90 \\
\hline 23 & 7 & 223 & 182 & 405 & 57.86 \\
\hline 24 & 5 & 120 & 126 & 246 & 49.20 \\
\hline 25 & 9 & 325 & 318 & 643 & 71.44 \\
\hline 26 & 10 & 256 & 253 & 509 & 50.90 \\
\hline 27 & 13 & 250 & 209 & 459 & 35.31 \\
\hline 28 & 11 & 291 & 278 & 569 & 51.73 \\
\hline 29 & 12 & 285 & 272 & 557 & 46.42 \\
\hline 30 & 12 & 288 & 269 & 557 & 46.42 \\
\hline 31 & 5 & 130 & 99 & 229 & 45.80 \\
\hline 32 & 14 & 64 & 62 & 126 & 9.00 \\
\hline 33 & 3 & 29 & 22 & 51 & 17.00 \\
\hline 34 & 2 & 34 & 37 & 71 & 35.50 \\
\hline 35 & 3 & 68 & 70 & 138 & 46.00 \\
\hline 36 & 12 & 211 & 200 & 411 & 34.25 \\
\hline 37 & 2 & 48 & 47 & 95 & 47.50 \\
\hline 38 & 4 & 83 & 62 & 145 & 36.25 \\
\hline 39 & 8 & 71 & 84 & 155 & 19.38 \\
\hline 40 & 6 & 174 & 189 & 363 & 60.50 \\
\hline 41 & 14 & 283 & 308 & 591 & 42.21 \\
\hline 42 & 3 & 64 & 59 & 123 & 41.00 \\
\hline 43 & 5 & 71 & 71 & 142 & 28.40 \\
\hline 44 & 7 & 149 & 143 & 292 & 41.71 \\
\hline 45 & 6 & 106 & 99 & 205 & 34.17 \\
\hline 46 & 3 & 74 & 86 & 160 & 53.33 \\
\hline
\end{tabular}


Paper-Learning Analytics: Issues on the Pupil-Teacher Ratio Dataset in Public Primary Schools...

\begin{tabular}{|c|c|c|c|c|c|}
\hline 47 & 8 & 147 & 157 & 304 & 38.00 \\
\hline 48 & 7 & 151 & 163 & 314 & 44.86 \\
\hline 49 & 8 & 136 & 153 & 289 & 36.13 \\
\hline 50 & 6 & 83 & 98 & 181 & 30.17 \\
\hline 51 & 8 & 142 & 134 & 276 & 34.50 \\
\hline 52 & 14 & 350 & 350 & 700 & 50.00 \\
\hline 53 & 3 & 68 & 67 & 135 & 45.00 \\
\hline 54 & 7 & 122 & 149 & 271 & 38.71 \\
\hline 55 & 12 & 215 & 206 & 421 & 35.08 \\
\hline 56 & 16 & 254 & 262 & 516 & 32.25 \\
\hline 57 & 9 & 222 & 213 & 435 & 48.33 \\
\hline 58 & 11 & 370 & 316 & 686 & 62.36 \\
\hline 59 & 5 & 157 & 153 & 310 & 62.00 \\
\hline 60 & 12 & 396 & 393 & 789 & 65.75 \\
\hline 61 & 4 & 77 & 62 & 139 & 34.75 \\
\hline 62 & 9 & 342 & 348 & 690 & 76.67 \\
\hline 63 & 7 & 247 & 218 & 465 & 66.43 \\
\hline 64 & 9 & 249 & 218 & 467 & 51.89 \\
\hline 65 & 4 & 67 & 84 & 151 & 37.75 \\
\hline 66 & 5 & 108 & 111 & 219 & 43.80 \\
\hline 67 & 3 & 57 & 63 & 120 & 40.00 \\
\hline 68 & 4 & 126 & 86 & 212 & 53.00 \\
\hline 69 & 4 & 72 & 88 & 160 & 40.00 \\
\hline 70 & 3 & 94 & 70 & 164 & 54.67 \\
\hline 71 & 5 & 215 & 180 & 395 & 79.00 \\
\hline 72 & 6 & 95 & 75 & 170 & 28.33 \\
\hline 73 & 4 & 62 & 38 & 100 & 25.00 \\
\hline 74 & 11 & 323 & 344 & 667 & 60.64 \\
\hline 75 & 5 & 155 & 142 & 297 & 59.40 \\
\hline 76 & 9 & 199 & 187 & 386 & 42.89 \\
\hline 77 & 4 & 133 & 139 & 272 & 68.00 \\
\hline 78 & 6 & 81 & 96 & 177 & 29.50 \\
\hline 79 & 5 & 112 & 124 & 236 & 47.20 \\
\hline 80 & 4 & 170 & 155 & 325 & 81.25 \\
\hline 81 & 6 & 151 & 153 & 304 & 50.67 \\
\hline 82 & 12 & 335 & 271 & 606 & 50.50 \\
\hline 83 & 3 & 110 & 97 & 207 & 69.00 \\
\hline 84 & 8 & 303 & 260 & 563 & 70.38 \\
\hline 85 & 10 & 333 & 293 & 626 & 62.60 \\
\hline 86 & 6 & 83 & 66 & 149 & 24.83 \\
\hline 87 & 6 & 185 & 158 & 343 & 57.17 \\
\hline 88 & 9 & 258 & 224 & 482 & 53.56 \\
\hline 89 & 10 & 266 & 251 & 517 & 51.70 \\
\hline 90 & 10 & 290 & 251 & 541 & 54.10 \\
\hline 91 & 6 & 108 & 94 & 202 & 33.67 \\
\hline 92 & 8 & 228 & 188 & 416 & 52.00 \\
\hline 93 & 9 & 222 & 221 & 443 & 49.22 \\
\hline 94 & 4 & 179 & 153 & 332 & 83.00 \\
\hline 95 & 4 & 129 & 47 & 176 & 44.00 \\
\hline
\end{tabular}


Paper-Learning Analytics: Issues on the Pupil-Teacher Ratio Dataset in Public Primary Schools...

\begin{tabular}{|c|c|c|c|c|c|}
\hline 96 & 5 & 225 & 247 & 472 & 94.40 \\
\hline 97 & 8 & 246 & 250 & 496 & 62.00 \\
\hline 98 & 4 & 112 & 108 & 220 & 55.00 \\
\hline 99 & 4 & 145 & 151 & 296 & 74.00 \\
\hline 100 & 10 & 274 & 212 & 486 & 48.60 \\
\hline 101 & 14 & 352 & 346 & 698 & 49.86 \\
\hline 102 & 6 & 147 & 171 & 318 & 53.00 \\
\hline 103 & 6 & 148 & 139 & 287 & 47.83 \\
\hline 104 & 8 & 150 & 127 & 277 & 34.63 \\
\hline 105 & 4 & 122 & 129 & 251 & 62.75 \\
\hline 106 & 6 & 211 & 157 & 368 & 61.33 \\
\hline 107 & 4 & 98 & 112 & 210 & 52.50 \\
\hline 108 & 5 & 124 & 132 & 256 & 51.20 \\
\hline 109 & 12 & 296 & 273 & 569 & 47.42 \\
\hline 110 & 9 & 381 & 310 & 691 & 76.78 \\
\hline 111 & 7 & 129 & 123 & 252 & 36.00 \\
\hline 112 & 13 & 264 & 278 & 542 & 41.69 \\
\hline 113 & 7 & 196 & 188 & 384 & 54.86 \\
\hline 114 & 8 & 235 & 284 & 519 & 64.88 \\
\hline 115 & 13 & 299 & 293 & 592 & 45.54 \\
\hline 116 & 7 & 156 & 154 & 310 & 44.29 \\
\hline 117 & 13 & 218 & 221 & 439 & 33.77 \\
\hline 118 & 12 & 206 & 187 & 393 & 32.75 \\
\hline 119 & 12 & 226 & 241 & 467 & 38.92 \\
\hline 120 & 12 & 235 & 247 & 482 & 40.17 \\
\hline 121 & 15 & 250 & 207 & 457 & 30.47 \\
\hline 122 & 11 & 292 & 253 & 545 & 49.55 \\
\hline 123 & 13 & 369 & 321 & 690 & 53.08 \\
\hline 124 & 9 & 244 & 245 & 489 & 54.33 \\
\hline 125 & 11 & 160 & 183 & 343 & 31.18 \\
\hline 126 & 13 & 224 & 179 & 403 & 31.00 \\
\hline 127 & 9 & 193 & 203 & 396 & 44.00 \\
\hline 128 & 11 & 218 & 262 & 480 & 43.64 \\
\hline 129 & 14 & 294 & 259 & 553 & 39.50 \\
\hline 130 & 12 & 203 & 214 & 417 & 34.75 \\
\hline 131 & 8 & 222 & 185 & 407 & 50.88 \\
\hline 132 & 8 & 190 & 176 & 366 & 45.75 \\
\hline
\end{tabular}

The distribution of the population of teachers, male and female students are shown in Figures 1, 2 and 3. 


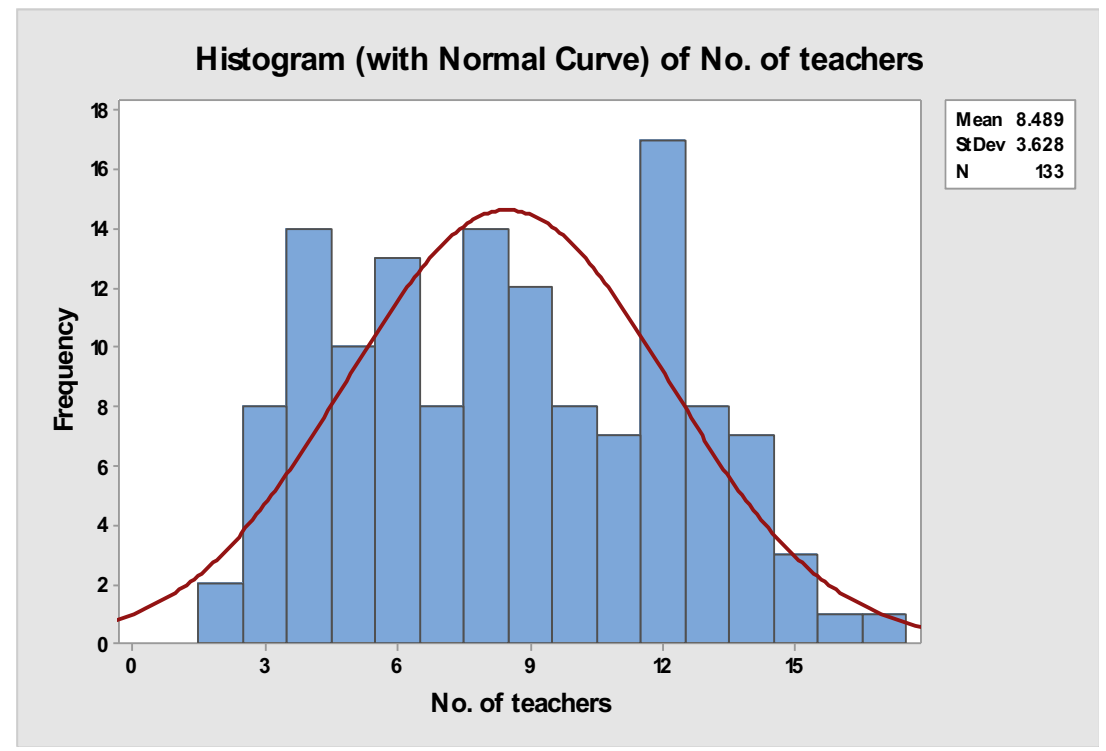

Fig. 1. Histogram showing the distribution of teachers across the LGA

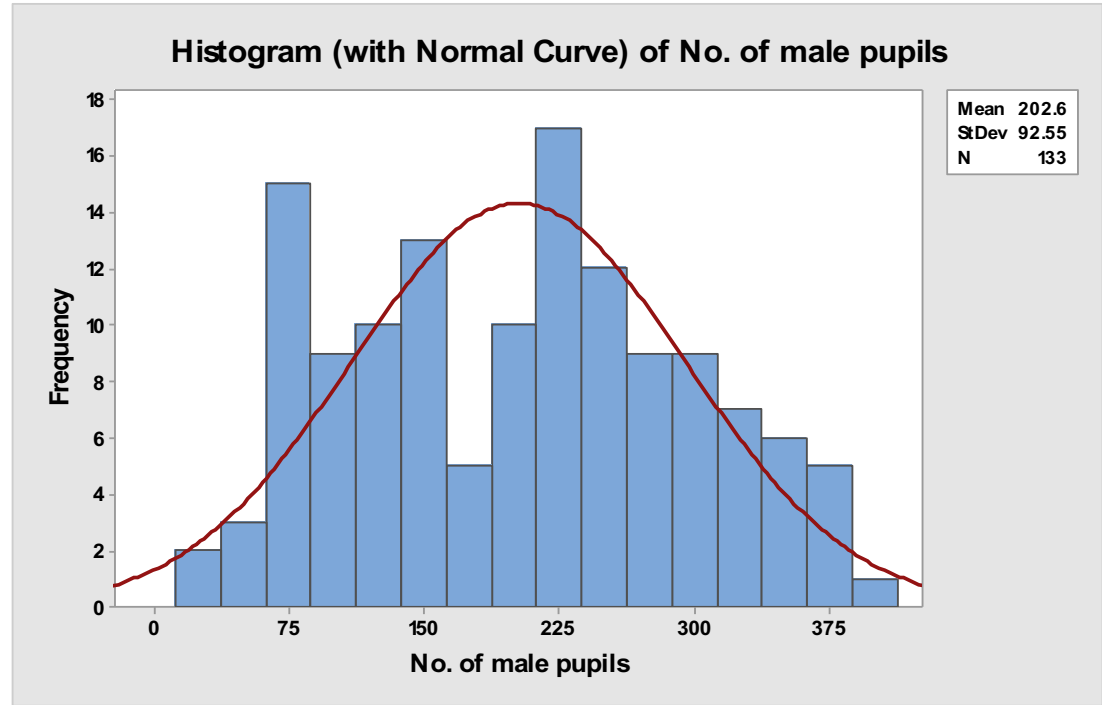

Fig. 2. Histogram showing the distribution of male pupils across the LGA 


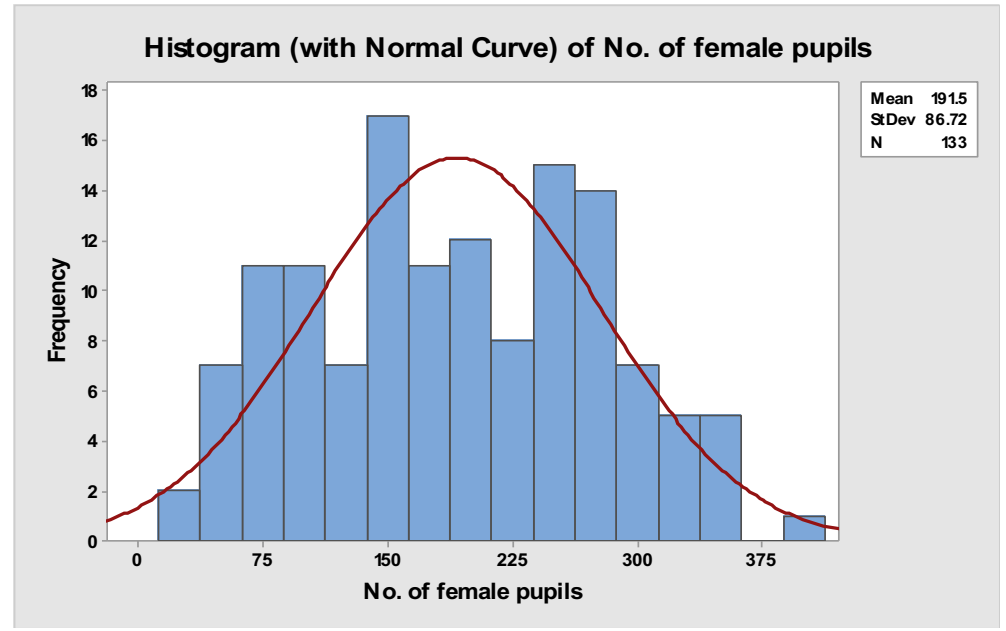

Fig. 3. Histogram showing the distribution of female pupils across the LGA

The descriptive statistics on the variables; teacher, number of male pupils and number of female pupils is presented in Table 3.

Table 3. Descriptive Statistics: No. of teachers, No. of male pupils, No. of female pupils

\begin{tabular}{|l|c|c|c|c|c|}
\hline \multicolumn{1}{|c|}{ Variable } & Mean & Sum & Median & Skewness & Kurtosis \\
\hline No. of teachers & 8.489 & 1129.000 & 8.000 & 0.14 & -1.01 \\
\hline No. of male pupils & 202.64 & 26951.00 & 211.00 & 0.09 & -0.95 \\
\hline No. of female pupils & 191.50 & 25469.00 & 188.00 & 0.05 & -0.92 \\
\hline
\end{tabular}

Remark: The schools across the LGA considered recorded more male pupils (26951) than female pupils (25469).

\subsection{PTR Ranking}

It is clear to all the PTR is not the same for all the schools considered as seen in Table 2. It is then necessary to know the schools with high PTR (PTR of more than say 35). The ranks of the schools considered based on their pupil-teacher ratio is presented in Table 4. The PTR was arranged from the highest to the lowest values. The ranking yielded three non-overlapping groups which are distinctly colored.

Table 4. The rank of the 133 schools based on the values of their PTR

\begin{tabular}{|c|c|c|c|}
\hline S/n & Teacher & Total & Pupil-teacher ratio \\
\hline 96 & 5 & 472 & 94.40 \\
\hline 94 & 4 & 332 & 83.00 \\
\hline 80 & 4 & 325 & 81.25 \\
\hline 71 & 5 & 395 & 79.00 \\
\hline 110 & 9 & 691 & 76.78 \\
\hline 62 & 9 & 690 & 76.67 \\
\hline 99 & 4 & 296 & 74.00 \\
\hline
\end{tabular}


Paper-Learning Analytics: Issues on the Pupil-Teacher Ratio Dataset in Public Primary Schools...

\begin{tabular}{|c|c|c|c|}
\hline 25 & 9 & 643 & 71.44 \\
\hline 84 & 8 & 563 & 70.38 \\
\hline 83 & 3 & 207 & 69.00 \\
\hline 77 & 4 & 272 & 68.00 \\
\hline 63 & 7 & 465 & 66.43 \\
\hline 60 & 12 & 789 & 65.75 \\
\hline 114 & 8 & 519 & 64.88 \\
\hline 105 & 4 & 251 & 62.75 \\
\hline 85 & 10 & 626 & 62.60 \\
\hline 58 & 11 & 686 & 62.36 \\
\hline 59 & 5 & 310 & 62.00 \\
\hline 97 & 8 & 496 & 62.00 \\
\hline 106 & 6 & 368 & 61.33 \\
\hline 74 & 11 & 667 & 60.64 \\
\hline 40 & 6 & 363 & 60.50 \\
\hline 75 & 5 & 297 & 59.40 \\
\hline 1 & 9 & 532 & 59.11 \\
\hline 23 & 7 & 405 & 57.86 \\
\hline 87 & 6 & 343 & 57.17 \\
\hline 12 & 13 & 735 & 56.54 \\
\hline 14 & 8 & 448 & 56.00 \\
\hline 16 & 8 & 447 & 55.88 \\
\hline 98 & 4 & 220 & 55.00 \\
\hline 113 & 7 & 384 & 54.86 \\
\hline 70 & 3 & 164 & 54.67 \\
\hline 124 & 9 & 489 & 54.33 \\
\hline 133 & 10 & 543 & 54.30 \\
\hline 90 & 10 & 541 & 54.10 \\
\hline 20 & 12 & 648 & 54.00 \\
\hline 88 & 9 & 482 & 53.56 \\
\hline 46 & 3 & 160 & 53.33 \\
\hline 123 & 13 & 690 & 53.08 \\
\hline 68 & 4 & 212 & 53.00 \\
\hline 102 & 6 & 318 & 53.00 \\
\hline 107 & 4 & 210 & 52.50 \\
\hline 11 & 12 & 628 & 52.33 \\
\hline 3 & 11 & 575 & 52.27 \\
\hline 13 & 12 & 624 & 52.00 \\
\hline 92 & 8 & 416 & 52.00 \\
\hline 64 & 9 & 467 & 51.89 \\
\hline 28 & 11 & 569 & 51.73 \\
\hline 89 & 10 & 517 & 51.70 \\
\hline 108 & 5 & 256 & 51.20 \\
\hline 26 & 10 & 509 & 50.90 \\
\hline 131 & 8 & 407 & 50.88 \\
\hline 81 & 6 & 304 & 50.67 \\
\hline 82 & 12 & 606 & 50.50 \\
\hline 10 & 14 & 704 & 50.29 \\
\hline 52 & 14 & 700 & 50.00 \\
\hline
\end{tabular}


Paper-Learning Analytics: Issues on the Pupil-Teacher Ratio Dataset in Public Primary Schools...

\begin{tabular}{|c|c|c|c|}
\hline 101 & 14 & 698 & 49.86 \\
\hline 122 & 11 & 545 & 49.55 \\
\hline 93 & 9 & 443 & 49.22 \\
\hline 24 & 5 & 246 & 49.20 \\
\hline 100 & 10 & 486 & 48.60 \\
\hline 57 & 9 & 435 & 48.33 \\
\hline 5 & 12 & 577 & 48.08 \\
\hline 103 & 6 & 287 & 47.83 \\
\hline 19 & 9 & 429 & 47.67 \\
\hline 37 & 2 & 95 & 47.50 \\
\hline 109 & 12 & 569 & 47.42 \\
\hline 79 & 5 & 236 & 47.20 \\
\hline 29 & 12 & 557 & 46.42 \\
\hline 30 & 12 & 557 & 46.42 \\
\hline 35 & 3 & 138 & 46.00 \\
\hline 31 & 5 & 229 & 45.80 \\
\hline 132 & 8 & 366 & 45.75 \\
\hline 115 & 13 & 592 & 45.54 \\
\hline 6 & 8 & 362 & 45.25 \\
\hline 53 & 3 & 135 & 45.00 \\
\hline 48 & 7 & 314 & 44.86 \\
\hline 116 & 7 & 310 & 44.29 \\
\hline 95 & 4 & 176 & 44.00 \\
\hline 127 & 9 & 396 & 44.00 \\
\hline 66 & 5 & 219 & 43.80 \\
\hline 128 & 11 & 480 & 43.64 \\
\hline 18 & 15 & 651 & 43.40 \\
\hline 76 & 9 & 386 & 42.89 \\
\hline 7 & 12 & 514 & 42.83 \\
\hline 41 & 14 & 591 & 42.21 \\
\hline 15 & 13 & 547 & 42.08 \\
\hline 44 & 7 & 292 & 41.71 \\
\hline 112 & 13 & 542 & 41.69 \\
\hline 42 & 3 & 123 & 41.00 \\
\hline 120 & 12 & 482 & 40.17 \\
\hline 67 & 3 & 120 & 40.00 \\
\hline 69 & 4 & 160 & 40.00 \\
\hline 129 & 14 & 553 & 39.50 \\
\hline 119 & 12 & 467 & 38.92 \\
\hline 54 & 7 & 271 & 38.71 \\
\hline 9 & 17 & 650 & 38.24 \\
\hline 8 & 14 & 532 & 38.00 \\
\hline 47 & 8 & 304 & 38.00 \\
\hline 65 & 4 & 151 & 37.75 \\
\hline 2 & 15 & 565 & 37.67 \\
\hline 38 & 4 & 145 & 36.25 \\
\hline 49 & 8 & 289 & 36.13 \\
\hline 4 & 12 & 432 & 36.00 \\
\hline 111 & 7 & 252 & 36.00 \\
\hline
\end{tabular}




\begin{tabular}{|c|c|c|c|}
\hline 34 & 2 & 71 & 35.50 \\
\hline 27 & 13 & 459 & 35.31 \\
\hline 55 & 12 & 421 & 35.08 \\
\hline 22 & 10 & 349 & 34.90 \\
\hline 61 & 4 & 139 & 34.75 \\
\hline 130 & 12 & 417 & 34.75 \\
\hline 104 & 8 & 277 & 34.63 \\
\hline 51 & 8 & 276 & 34.50 \\
\hline 17 & 10 & 343 & 34.30 \\
\hline 36 & 12 & 411 & 34.25 \\
\hline 45 & 6 & 205 & 34.17 \\
\hline 117 & 13 & 439 & 33.77 \\
\hline 91 & 6 & 202 & 33.67 \\
\hline 118 & 12 & 393 & 32.75 \\
\hline 56 & 16 & 516 & 32.25 \\
\hline 125 & 11 & 343 & 31.18 \\
\hline 126 & 13 & 403 & 31.00 \\
\hline 121 & 15 & 457 & 30.47 \\
\hline 50 & 6 & 181 & 30.17 \\
\hline 78 & 6 & 177 & 29.50 \\
\hline 21 & 6 & 176 & 29.33 \\
\hline 43 & 5 & 142 & 28.40 \\
\hline 72 & 6 & 170 & 28.33 \\
\hline 73 & 4 & 100 & 25.00 \\
\hline 86 & 6 & 149 & 24.83 \\
\hline 39 & 8 & 155 & 19.38 \\
\hline 33 & 3 & 51 & 17.00 \\
\hline 32 & 14 & 126 & 9.00 \\
\hline
\end{tabular}

The current PTR in Nigeria is 35, that is, 35 pupils to a teacher. 56 schools with red color have high PTR and requires more teachers to reduce the value of the PTR, which is PTR of 50 and above. However, those with yellow color are adjudged to be acceptable (25 schools), which is PTR of 35 and below. The acceptability is subject to interpretation from the Nigerian context, because the survey area is one of the educational developed states in Nigeria and, ordinarily, it is expected that the PTR should be small. However, this article points to the contrary. Moreover, it is expected that PTR should be high in education less developed states of the country which are the northern and the Niger Delta area of the country.

\section{Conclusion}

The research had led to the following conclusions:

- Only 25 (19\%) schools out of the 133 schools considered have an acceptable PTR (below 35).

- $52(39 \%)$ schools out of the 133 schools considered have a moderate PTR (between 35 and 50). 
- $56(42 \%)$ schools out of the 133 schools considered have unacceptable and high PTR (above 50).

- More qualified teachers are urgently needed in these schools in order to ensure effective teaching and learning are taking place

- Adequate funding should be provided by the government to sustain these schools and to ensure that these pupils are not deprived of their basic rights.

This research will be helpful in educational evaluation and assessment, audit and quality assurance, to decision makers in the Ministry of Education in gap analysis for recruitment purposes, assessing the level of implementation of policies on education and to monitor the progress made in attaining development sustainable goals (SDG) as it relates to access to quality education.

\section{Acknowledgement}

The authors are grateful to Covenant University for providing an enabling environment for this research. The principals of all the schools considered are also acknowledged for giving the authors access to their register.

\section{$7 \quad$ References}

[1] Pupil-teacher ratio (PTR) http://uis.unesco.org/node/334770, accessed 01/07/2018.

[2] Ikediashi, N. N. \& Amaechi, O. N. (2012). Pupil-Teacher Ratio: Implication for Quality Education in Nigeria Primary Schools. AFRREV IJAH: An Int. J. Arts Humanities, 1(1) (2012) 257-264.

[3] Bishop, S. A., Owoloko, E. A., Okagbue, H. I., Oguntunde, P. E., Odetunmibi, O. A. \& Opanuga, A. A. (2017). Survey datasets on the externalizing behaviors of primary school pupils and secondary school students in some selected schools in Ogun State, Nigeria. Data in Brief, 13, 469-479. https://doi.org/10.1016/j.dib.2017.06.025

[4] Adelabu, M. A. (2005). Teacher motivation and incentives in Nigeria. London: DFID.

[5] Asagwara, K. C. P. (1997). Quality of learning in Nigeria's universal primary education scheme-1976-1986. The Urban Review, 29 (3), 189-203.

[6] Tooley, J., Dixon, P. \& Olaniyan, O. (2005). Private and public schooling in low-income areas of Lagos State, Nigeria: A census and comparative survey. Int. J. Educ. Res., 43(3), 125-146. https://doi.org/10.1016/j.ijer.2006.05.001

[7] Asikhia, O. A. (2010). Students and teachers' perception of the causes of poor academic performance in Ogun State secondary schools [Nigeria]: Implications for counseling for national development. Euro. J. Soc. Sci., 13(2), 229-242.

[8] Härmä, J. (2013). Access or quality? Why do families living in slums choose low-cost private schools in Lagos, Nigeria? Oxford Rev. Educ., 39 (4), 548-566. https://doi.org/ $10.1080 / 03054985.2013 .825984$

[9] Moja, T. (2000). Nigeria education sector analysis: An analytical synthesis of performance and main issues. World Bank Report, 3, 46-56.

[10] Nishimura, M. \& Yamano, T. (2013). Emerging Private Education in Africa: Determinants of School Choice in Rural Kenya. World Development, 43, 266-275. https://doi.org/ 10.1016/j.worlddev.2012.10.001

[11] Joanis, M. (2013). Sharing the blame? Local electoral accountability and centralized school finance in California. Economics and Politics, 25 (3), 335-359. https://doi.org/ $\underline{10.1111 / \text { ecpo. } 12015}$ 
[12] Craigwell, R., Bynoe, D. \& Lowe, S. (2012). The effectiveness of government expenditure on education and health care in the Caribbean. Int. J. Develop. Issues, 11 (1), 4-18. https://doi.org/10.1108/14468951211213831

[13] Kelly, A. S. \& Burdeane Orris, J. (2011). Assessing accountability in U.S. public education. Journal of Public Budgeting, Accounting and Financial Management, 23 (1), 1-30. https://doi.org/10.1108/jpbafm-23-01-2011-b001

[14] Tooley, J., Dixon, P., Gomathi, S. V. (2007). Private schools and the millennium development goal of universal primary education: A census and comparative survey in Hyderabad, India. Oxford Rev. Educ., 33 (5), 539-560. https://doi.org/10.1080/03054980701425664

[15] Rjéoutski, V. (2005). Foreign schools in Russian society during the age of enlightenment. Cahiers du Monde Russe, 46 (3), 473-528.

[16] Graue, E., Hatch, K., Rao, K. \& Oen, D. (2007). The wisdom of class-size reduction. Amer. Educ. Res. J., 44 (3), 670-700. https://doi.org/10.3102/0002831207306755

[17] Sherman, J. D. (2009). Regional disparities in primary school participation in developing countries. Prospects, 38 (3), 305-323. https://doi.org/10.1007/s11125-009-9087-0

[18] Van Der Berg, S. (2006). The targeting of public spending on school education, 1995 and 2000. Perspectives in Education, 24 (2), 49-63.

[19] Garnier, M. \& Schafer, M. (2006). Educational model and expansion of enrollments in sub-Saharan Africa. Sociology of Education, 79 (2), 153-176. https://doi.org/10.1177/ 003804070607900204

[20] Mingat, A. \& Tan, J.-P. (2003). On the mechanics of progress in primary education. Economics of Education Review, 22 (5), 455-467.https://doi.org/10.1016/s02727757 (03)00036-0

[21] Hartley, D. (2003). New economy, new pedagogy? Oxford Review of Education, 29 (1), 81-94.

[22] Gundlach, E. \& Wössmann, L. (2001). The fading productivity of schooling in East Asia. Journal of Asian Economics, 12 (3), 401-417.https://doi.org/10.1016/s10490078(01)00094-x

[23] Mundia, L. (2007). Early childhood education in Swaziland and Brunei Darussalam: Goals, achievements and challenges. Early Child Development and Care, 177 (2), 151158.https://doi.org/10.1080/03004430500375885

[24] Gong, Y. (2018). Innovative English classroom teaching based on online computer technology in rural middle and primary schools. International Journal of Emerging Technologies in Learning, 13 (10), 4-14. https://doi.org/10.3991/ijet.v13i10.9449

[25] Baglama, B., Haksiz, M. \& Uzunboylu, H. (2018). Technologies used in education of hearing-impaired individuals. International Journal of Emerging Technologies in Learning, 13 (9), 53-63. https://doi.org/10.3991/ijet.v13i09.8303

[26] Ros-Morente, A., Cuenca, E. C. \& Filella-Guiu, G. (2018). Analysis of the effects of two gamified emotional education software's in emotional and well-being variables in Spanish children and adolescents. International Journal of Emerging Technologies in Learning, 13 (9), 148-159. https://doi.org/10.3991/ijet.v13i09.7841

[27] Ismail, O. A., Mahmood, A. K. \& Abdelmaboud, A. (2018). Factors influencing academic performance of students in blended and traditional domains. International Journal of Emerging Technologies in Learning, 13 (2), 170-187. https://doi.org/10.39 91/ijet.v13i02.8031

[28] Villányi, D., Martin, R., Sonnleitner, P., Siry, C. \& Fischbach, A. (2018). A tabletcomputer-based tool to facilitate accurate self-assessments in third- and fourth-graders. International Journal of Emerging Technologies in Learning, 13 (10), 225-251. https://doi.org/10.3991/ijet.v13i10.8876

[29] Ismail, N. A. \& Cheng, A.G. (2005). Analysing education production in Malaysia using canonical correlation analysis. Int. Educ. J., 6 (3), 308-315.

[30] Hungi, N. \& Thuku, F. W. (2010). Differences in pupil achievement in Kenya: Implications for policy and practice. Int. J. Educ. Develop., 30 (1), 33-43. https://doi.org/10.10 16/j.ijedudev.2009.05.001

[31] Edwards, S. \& Garcia Marin, A. (2015). Constitutional rights and education: An international comparative study. J. Compar. Econ., 43 (4), 938-955. 
[32] Wakori, K. S. (2014). Factors affecting performance in the Kenya certificate of primary education a case of Kirinyaga west district Kenya. Medit. J. Soc. Sci., 5 (5), 273-295. https://doi.org/10.5901/mjss.2014.v5n5p273

[33] Maji, K. \& Sarkar, S. (2017). Intra-district disparities in primary education: A case study of Bankura District, West Bengal. Space and Culture, India, 4 (3), 77-92. https://doi.org/10.20896/saci.v4i3.214

[34] Cheung, H. Y. \& Chan, A. W. H. (2008). Relationships amongst cultural dimensions, educational expenditure and class size of different nations. Int. J. Educ. Develop., 28 (6), 698707. https://doi.org/10.1016/j.ijedudev.2007.11.003

[35] Talbott, E., Fleming, J., Karabatsos, G. \& Dobria, L. (2011). Making sense of minority student identification in special education: School context matters. Int. J. Special Educ., 26 (3), 150-170.

[36] Maligalig, D. S., Caoli-Rodriguez, R. B., Martinez Jr., A. \& Cuevas, S. (2010). Education outcomes in the Philippines. ADB Economics Working Paper Series, 199, 1-73. https://doi.org/10.2139/ssrn.1632682

[37] Sarin, M. N. (2015). Quality education for all? A case study of a New Delhi government school. Policy Fut. Educ., 13 (3), 360-374. https://doi.org/10.1177/1478210315569042

[38] Dee, T. S. \& Fu, H. (2004). Do charter schools skim students or drain resources? Econ. Educ. Rev., 23 (3), 259-271. https://doi.org/10.1016/i.econedurev.2003.10.001

[39] Baird, J., Ma, S. \& Ruger, J. P. (2011). Effects of the World Bank's maternal and child health intervention on Indonesia's poor: Evaluating the safe motherhood project. Soc. Sci. Med., 72 (12), 1948-1955. https://doi.org/10.1016/j.socscimed.2010.04.038

[40] Hatsor, L. (2012). Occupational choice: Teacher quality versus teacher quantity. Labour Economics, 19 (4), 608-623. https://doi.org/10.1016/j.labeco.2012.05.003

[41] Edwards, F. (2005). The neglected heart of educational development: Primary teacher education strategy in Malawi. J. Educ. Teaching, 31 (1), 25-36. https://doi.org/10.1080/ 02607470500043557

[42] Li, M. \& Tobias, J. L. (2003). A semiparametric investigation of the school qualityearnings relationship. Appl. Econ. Lett. 10 (1), 43-45.

[43] Ervasti, J., Kivimäki, M., Kawachi, I., Subramanian, S. V., Pentti, J., Ahola, K., Oksanen, T., Pohjonen, T., Vahtera, J., Virtanen, M. (2012). Pupils with special educational needs in basic education schools and teachers' sickness absences - a register-linkage study. Scand. J. Work, Environ. Health, 38 (3), 209-217. https://doi.org/10.5271/sjweh.3281

[44] Van Houtte, E., Claeys, S., Wuyts, F. \& Van Lierde, K. (2012). Voice disorders in teachers: Occupational risk factors and psycho-emotional factors. Logopedics Phoniatrics Vocology, 37 (3), 107-116. https://doi.org/10.3109/14015439.2012.660499

[45] Chennoufi, L., Ellouze, F., Cherif, W., Mersni, M., M'Rad, M. F. (2012). Stress and burnout among Tunisian teachers. Encephale, 38 (6), 480-487. https://doi.org/10.1 016/j.encep.2011.12.012

[46] Heinesen, E. \& Graversen, B. K. (2005). The effect of school resources on educational attainment: Evidence from Denmark. Bull. Econ. Res., 57 (2), 109-143. https://doi.org/10.1111/j.0307-3378.2005.00217.x

[47] El Husseiny, I. A. \& Amin, K. Z. (2018). Pre-university education outputs in Egypt: Does money matter? International J. Educ. Econ. Develop., 9 (3), 210-235. https://doi.org/10.15 04/ijeed.2018.10015390

[48] Brunello, G. \& Checchi, D. (2005). School quality and family background in Italy. Econ. Educ. Rev., 24 (5), 563-577. https://doi.org/10.1016/j.econedurev.2004.09.001

[49] Bowman-Perrott, L. J., Greenwood, C. R. \& Tapia, Y. (2007). The efficacy of CWPT used in secondary alternative school classrooms with small teacher/pupil ratios and students with emotional and behavioral disorders. Educ. Treat. Children, 30 (3), 65-87. https://doi.org/10.1353/etc.2007.0014

[50] Gil-Flores, J. \& García-Gómez, S. (2017). The importance of teaching practices in relation to regional educational policies in explaining PISA achievement. Revista de Educacion, 2017 (378), 52-74.

[51] Suryadarma, D., Suryahadi, A., Sumarto, S. \& Rogers, F. H. (2006). Improving student performance in public primary schools in developing countries: Evidence from Indonesia. Educ. Econ., 14 (4), 401-429. https://doi.org/10.1080/09645290600854110 
[52] Iatarola, P., Schwartz, A., Stiefel, L. \& Chellman, C. C. (2008). Small schools, large districts: Small-school reform and New York City's students. Teach. Coll. Rec., 110 (9), 1837-1878.

[53] Knabb, S. D. \& Stoddard, C. (2005). The quality of education, educational institutions, and cross-country differences in human capital accumulation. Growth and Change, 36 (3), 354-373. https://doi.org/10.1111/j.1468-2257.2005.00281.x

[54] Brunello, G. \& Cappellari, L. (2008). The labour market effects of Alma Mater: Evidence from Italy. Econ. Educ. Rev., 27 (5), 564-574. https://doi.org/10.1016/j.econedurev. 2007.05.004

[55] Grawe, N. D. (2010). Primary and secondary school quality and intergenerational earnings mobility. J. Human Capital, 4 (4), 331-364. https://doi.org/10.1086/658855

[56] Eide, E. R. \& Showalter, M. H. (2005). Does improving school quality reduce the probability of unemployment? Contem. Econ. Policy, 23 (4), 578-584. https://doi.org/10.1 093/cep/byi042

[57] Frisvold, D. \& Golberstein, E. (2011). School quality and the education-health relationship: Evidence from Blacks in segregated schools. J. Health Econ., 30 (6), 1232-1245. https://doi.org/10.1016/j.jhealeco.2011.08.003

[58] Li, M. (2007). Bayesian proportional hazard analysis of the timing of high school dropout decisions. Econometric Reviews, 26 (5), 529-556. https://doi.org/10.1080/074749930 701509416

[59] Mora, T., Escardíbul, J.- O. \& Espasa, M. (2010). The effects of regional educational policies on school failure in Spain. Revista de Economia Aplicada, 18 (54), 79-106.

[60] Bratsberg, B. \& Terrell, D. (2002). School quality and returns to education of U.S. immigrants. Economic Inquiry, 40 (2), 177-198. https://doi.org/10.1093/ei/40.2.177

[61] Graddy, K. \& Stevens, M. (2005). The impact of school resources on student performance: A study of private schools in the United Kingdom. Indus. Labor Relat. Rev., 58 (3), $435-$ 451 https://doi.org/10.1177/001979390505800307

[62] Arora, R. U. (2012). Financial Inclusion and Human Capital in Developing Asia: The Australian connection. Third World Quarterly, 33 (1), 179-199. https://doi.org/10.108 $0 / 01436597.2012 .627256$

[63] Kirabo Jackson, C., Johnson, R. C. \& Persico, C. (2016). The effects of school spending on educational and economic outcomes: Evidence from school finance reforms. Quart. J. Econ., 131 (1), 157-218. https://doi.org/10.3386/w20847

[64] Lewin, K. M. (2006). Costs and finance of multigrade strategies for learning: How do the books balance? Education for All and Multigrade Teaching, 239-263. https://doi.org/10.1007/1-4020-4591-3 12

[65] Baldwin, N. \& Borrelli, S. A. (2008). Education and economic growth in the United States: Cross-national applications for an intra-national path analysis. Policy Sciences, 41 (3), 183-204. https://doi.org/10.1007/s11077-008-9062-2

[66] Houck, E. A. (2010). Teacher quality and school resegregation: A resource allocation case study. Leadership and Policy in Schools, 9 (1), 49-77.https://doi.org/10.1080/ 15700760802630210

[67] Yawe, B. L. (2012). Policy incoherencies and research gaps in Uganda's primary education sub-sector. Int. J. Social Ecol. Sust. Develop., 3 (1), 38-52.https://doi.org/10. 4018/jsesd.2012010103

[68] Yawe, B. L. (2014). Policy coherence for development: A case study of Uganda's primary education sub-sector. Educational Technology Use and Design for Improved Learning Opportunities, 213-232. https://doi.org/10.4018/978-1-4666-6102-8.ch012

[69] Rose, H. \& Sonstelie, J. (2010). School board politics, school district size, and the bargaining power of teachers' unions. Journal of Urban Economics, 67 (3), 438-450. https://doi.org/10.1016/i.jue.2010.01.001

[70] Brunner, E. J. \& Squires, T. (2013). The bargaining power of teachers' unions and the allocation of school resources. Journal of Urban Economics, 76 (1), 15-27. https://doi.org/10.1016/j.jue.2013.01.003

[71] Stoddard, C. (2003). Why has the number of teachers per student risen while teacher quality has declined? The role of changes in the labor market for women. J. Urban Econ., 53 (3), 458-481. https://doi.org/10.1016/s0094-1190(03)00004-4 
[72] Asongu, S. A. \& Odhiambo, N. M. (2018). Basic formal education quality, information technology, and inclusive human development in sub-Saharan Africa. Sustain. Develop., https://doi.org/10.1002/sd.1914. https://doi.org/10.1002/sd.1914

[73] Kassile, T. (2014). Pass rates in primary school leaving examination in Tanzania: Implication for efficient allocation of resources. South Afr. J. Educ., 34 (2). https://doi.org/10.157 00/201412071127

[74] Duflo, E., Dupas, P. \& Kremer, M. (2015). School governance, teacher incentives, and pupil-teacher ratios: Experimental evidence from Kenyan primary schools. J. Public Econ., 123, 92-110. https://doi.org/10.1016/j.jpubeco.2014.11.008

[75] Pugatch, T. \& Schroeder, E. (2014). Incentives for teacher relocation: Evidence from the Gambian hardship allowance. Econ. Educ. Rev., 41, 120-136. https://doi.org/10.101 6/j.econedurev.2014.04.003

[76] Ngware, M. W., Oketch, M. \& Ezeh, A. C. (2011). Quality of primary education inputs in urban schools: Evidence from Nairobi. Educ. Urban Soc., 43 (1), 91-116. https://doi.org/10.1177/0013124510379131

[77] Gamero Burón, C. \& Lassibille, G. (2016). Job Satisfaction among Primary School Personnel in Madagascar. J. Develop. Stud., 52 (11), 1628-1646. https://doi.org/10. $1080 / 00220388.2016 .1187726$

[78] Tsaurai, K. (2015). Does human capital development matter in fdi location decisions? A case for Austria. Risk Gov. Control: Fin. Mark. Inst., 5 (3), 26-35. https://doi.org/10.2 2495/rgcv5i3art3

[79] Baker, B. D. \& Weber, M. (2016). State school finance inequities and the limits of pursuing teacher equity through departmental regulation. Educ. Policy Analy. Arch., 24, Number 47. http://dx.doi.org/10.14507/epaa.24.2230. https://doi.org/10.14507/epaa.24.2230

[80] Chen, X. \& Moul, C. C. (2014). Disease or utopia? Testing Baumol in education. Econ. Lett., 122 (2), 220-223. https://doi.org/10.1016/j.econlet.2013.11.032

[81] Xie, H. \& Kang, J. (2009). Relationships between environmental noise and socialeconomic factors: Case studies based on NHS hospitals in Greater London. Renewable Energy, 34 (9), 2044-2053. https://doi.org/10.1016/j.renene.2009.02.012

[82] Baams, L., Pollitt, A. M., Laub, C. \& Russell, S. T. (2018). Characteristics of schools with and without Gay-Straight Alliances. Appl. Develop. Sci., https://doi.org/10.1080/ $\underline{10888691.2018 .1510778}$

[83] Tan, L., Xia, T. \& Reece, C. (2018). Social and individual risk factors for suicide ideation among Chinese children and adolescents: A multilevel analysis. Int. J. Psychol., 53 (2,) 117-125. https://doi.org/10.1002/ijop.12273

[84] Ransdell, S. (2012). There's Still No Free Lunch: Poverty as a Composite of SES Predicts School-Level Reading Comprehension. Amer. Behav. Scient., 56 (7), 908-925. https://doi.org/10.1177/0002764211408878

[85] Bischoff, I. \& Hauschildt, J. (2018). Vocational schools as an instrument of interregional competition-Empirical evidence from German counties. Jahrbuch fur Regionalwissenschaft. https://ideas.repec.org/p/mar/magkse/201722.html. https://doi.org/10.1007/s10037$018-0127-1$

[86] Wei, H.- S., Williams, J. H., Chen, J. -K. \& Chang, H. -Y. (2010). The effects of individual characteristics, teacher practice, and school organizational factors on students' bullying: A multilevel analysis of public middle schools in Taiwan. Children and Youth Services Review, 32 (1), 137-143. https://doi.org/10.1016/j.childyouth.2009.08.004

[87] van der Berg, S. (2007). Apartheid's enduring legacy: Inequalities in education. J. Afr. Econ., 16 (5), 849-880.

[88] McVicar, D. (2001). School quality and staying-on in Northern Ireland: Resources, peer groups and ethos. Econ. Soc. Rev., 32 (2), 131-151.

[89] Dearden, L., Ferri, J. \& Meghir, C. (2002). The effect of school quality on educational attainment and wages. Rev. Econ. Stat., 84 (1), 1-20.

[90] Speakman, R. \& Welch, F. (2006). Using Wages to Infer School Quality. Handbook of the Economics of Education, 2, 813-864. https://doi.org/10.1016/s1574-0692(06)02013-7

[91] Kuo, M., Browning, M. H. E. M., Sachdeva, S., Lee, K. \& Westphal, L. (2018). Might school performance grow on trees? Examining the link between "Greenness" and academic 
achievement in Urban, high-poverty schools. Front. Psychol., 9 (SEP), Art. 1669. https://doi.org/10.3389/fpsyg.2018.01669

[92] D'Aiglepierre, R. \& Wagner, L. (2013). Aid and Universal Primary Education. Econ. Educ. Rev., 37, 95-112.

[93] Betts, J. R. (2001). The impact of school resources on women's earnings and educational attainment: Findings from the national longitudinal survey of young women. J. Labor Econ., 19 (3), 635-657. https://doi.org/10.1086/322076

[94] Bhorat, H. \& Oosthuizen, M. (2009). Determinants of grade 12 pass rates in the postapartheid South African schooling system. J. Afr. Econ., 18 (4), 634-666. https://doi.org/10.1093/jae/ejn027

[95] Burns, M. K., Courtad, C. A., Hoffman, H. \& Folger, W. (2004). A comparison of districtlevel variables and state accountability test results for public elementary and middle schools. Psychol. Educ., 41 (2), 17-26.

[96] Odukoya, J. A., Popoola, S. I., Atayero, A. A., Omole, D. O., Badejo, J. A., John, T. M., \& Olowo, O. O. (2018). Learning analytics: Dataset for empirical evaluation of entry requirements into engineering undergraduate programs in a Nigerian university. Data in Brief, 17, 998-1014. https://doi.org/10.1016/j.dib.2018.02.025

[97] Okagbue, H. I., Erondu, E. C., Atayero, A. A., Oguntunde, P. E., Opanuga, A. A., Olawande, T. I., Ijezie, O. A. \& Eze, G. A. (2018). Statistical analysis of frequencies of opponents' eliminations in Royal Rumble wrestling matches, 1988-2018. Data in Brief, 19, 1458-1465. https://doi.org/10.1016/j.dib.2018.06.023

[98] Oguntunde, P., Okagbue, H., Oguntunde, O. A., \& Opanuga, A. (2018). Analysis of the inter-relationship between students' first year results and their final graduating grades. International Journal of Advanced and Applied Sciences, 5, 1-6.

[99] Popoola, S. I., Atayero, A. A., Badejo, J. A., Odukoya, J. A., Omole, D. O., \& Ajayi, P. (2018). Datasets on demographic trends in enrollment into undergraduate engineering programs at Covenant University, Nigeria. Data in Brief, 18, 47-59. https://doi.org/10.1 016/j.dib.2018.02.073

[100] Adekitan, A. I. \& Noma-Osaghae, E. (2018). Data mining approach to predicting the performance of first year student in a university using the admission requirements. Educ Inf Technol. https://doi.org/10.1007/s10639-018-9839-7.

\section{$7 \quad$ Authors}

Abiodun A Opanuga holds B.Sc (Ed) and M.Sc degrees in Mathematics from University of Ado-Ekiti and Olabisi Onabanjo University respectively. He bagged his $\mathrm{Ph} . \mathrm{D}$ degree at Covenant University in 2017. He is a lecturer and a researcher at Covenant University and has contributed to several scholarly journals.

Hilary I Okagbue Obtained his B.Tech and M.Sc degrees in Industrial Mathematics and Statistics from the Federal University of Technology, Owerri and University of Lagos in 2007 and 2010 respectively. He is currently on a Ph.D programme at Covenant University, Ota, Nigeria where he works as a researcher and Lecturer at the department of Mathematics. His research interests include: Data analysis, Mathematical Statistics, Mathematical Cryptography and analysis of patterns in number theory.

Pelumi E Oguntunde holds Bachelor of Science (B.Sc) and Master of Science (M.Sc) degrees in Statistics from University of Ilorin and University of Ibadan respectively. He bagged his Ph.D degree at Covenant University and his area of specialization is Mathematical Statistics. He is a lecturer and a researcher at Covenant University; he has contributed to several scholarly journals especially in the area of probability distribution theory. 
Sheila A Bishop holds N.C.E. Mathematics/Physics, B.Sc(Ed) Mathematics, M.Sc Mathematics and Ph.D degrees in Mathematics from the College of Education Benin, University of Benin, University of Ibadan and Covenant University respectively. She is a faculty in the Department of Mathematics, Covenant University, Nigeria. She has served in various committees at the Departmental, College and University levels from 2007 to date. She is currently the acting head of the Department of Mathematics, Covenant University, Nigeria. She has a teaching experience of over (2) decades in both public and private schools. She has supervised over ten (10) undergraduate students and currently supervising two (2) post graduate students. She has also served as examiner to several $\mathrm{PhD}$ thesis and a reviewer to some journals. She is a Mathematician with research interest in quantum stochastic differential equations, stochastic differential equations, ordinary differential equations, Mathematical Statistics. Some of her research activities in differential equations cover both qualitative and quantitative analysis of solutions. She also has interest in Mathematics education and Mathematical Physics.

Opeyemi P Ogundile received his B.Sc from Covenant University in Nigeria and proceeded to the prestigious university of Ibadan, Nigeria for his Master's in Mathematics. He is currently a faculty member at Covenant university, Nigeria and his areas of interest are Financial Mathematics, Mathematical Modeling, Stochastic (numerical) Differential Equation and Statistics.

Article submitted 2019-01-08. Resubmitted 2019-03-27. Final acceptance 2019-03-29. Final version published as submitted by the authors. 